\title{
DETERMINAN NILAI PERUSAHAAN PADA JAKARTA ISLAMIC INDEX 2015-2019
}

\author{
Ayu Franciska dan Rosyid Nur Anggara Putra \\ UIN Sunan Kalijaga Yogyakarta \\ Jl. Laksda Adisucipto, Papringan, Caturtunggal, Depok, Sleman, DI Yogyakarta 55281 \\ Email: ayufranciska2@gmail.com dan rosyid.putra@uin-suka.ac.id
}

\begin{abstract}
The purpose of this study is to examine the factors that influence firm value in manufacturing companies listed on the Jakarta Islamic Index (JII) for the 2015-2019 period. This study examines the effect of financial leverage, size, asset structure and corporate governance on firm value as measured by price to book value. The sample was determined by purposive sampling method and obtained 50 observation data. Research data collected form documentaion form the company's annual report. The analysis technique used is multiple regression analysis. The results show that financial leverage, size, asset structure and corporate governance have a positive and significant effect on firm value. Financial leverage ratio encourage the company to pay off the liability, so cab be said that the manufacturs company do the best perfomance to create firm value. Size have positive impact to firm value. The big size company can denote the growth of the company and make the positif signal for investor. The Assets Structure has positive impact on firm value indicating that the assets structure is used optimally, it will increase the company's return. Corporate Goverance has a positve effect on firm value where CEO Duality as indicator of corporate governance provide the strenght for top management and Independen Commisioner indicates the ability of the bord commissonerstoo make decisons more objectively.
\end{abstract}

Keywords: financial leverage, size, asset structure, corporate governance, firm value

\section{ABSTRAK}

Tujuan dari penelitian ini adalah untuk menguji faktor-faktor yang memengaruhi nilai perusahaan pada perusahaan manufaktur yang terdaftar di Jakarta Islamic Index (JII) periode 2015-2019. Penelitian ini menguji pengaruh financial leverage, size, asset structure dan corporate governance terhadap nilai perusahaan yang diukur dengan price to book value. Sampel ditentukan dengan metode purposive sampling dan diperoleh 50 data observasi. Data penelitian dikumpulkan dengan dokumentasi dari laporan tahunan perusahaan. Teknik analisis yang digunakan adalah analisis regresi berganda. Hasil penelitian menunjukkan bahwa financial leverage, size, struktur aset dan corporate governance berpengaruh positif dan signifikan terhadap nilai perusahaan. Rasio financial leverage memacu perusahaan untuk mampu melunasi hutangnya, sehingga dapat dikatakan bahwa perusahaan dalam sektor manufaktur sudah melakukan kinerja terbaik untuk menciptakan nilai perusahaan. Size memiliki pengaruh positif terhadap nilai perusahaan, Perusahaan berskala besar dapat menunjukkan kondisi perusahaan sedang mengalami perkembangan dan menjadikan sinyal yang baik bagi investor. Struktur aset berpengaruh positif terhadap nilai 
perusahaan mengindikasikan bahwa ketika aset tersebut dimanfaatkan secara optimal oleh perusahaan, maka akan meningkatkan return perusahaan. Corporate governance berpengaruh positif terhadap nilai perusahaan dimana CEO Duality sebagai indikator dari corporate governance memberikan kekuatan bagi manajemen puncak dan proporsi komisaris independen menandakan kemampuan dewan komisaris untuk mengambil keputusan semakin objektif.

Kata kunci: financial leverage, ukuran perusahaan, struktur aset, tata kelola perusahaan, nilai perusahaan

\section{PENDAHULUAN}

Perkembangan ekonomi menuntut suatu perusahaan untuk dapat menyesuaikan diri serta dapat membaca situasi yang terjadi seiring berjalannya waktu agar dapat mengelola perusahaan dengan baik dan tercipta keseimbangan dalam menjalankan suatu perusahaan. Tujuan perusahaan adalah kemakmuran bagi pemegang saham dan meningkatkan nilai pemegang saham sebagaimana tercermin dalam harga saham perusahaan. Rosada \& Idayati (2017) berpendapat bahwa nilai perusahaan sangat penting karena nilai perusahaan yang tinggi akan diikuti oleh pemegang saham dengan kemakmuran yang tinggi pula.

Safitri \& Wahyuati (2015) berpendapat bahwa maksimalisasi nilai perusahaan sangat dipengaruhi oleh ketersediaan dan akses terhadap sumber dana eksternal atau internal perusahaan. Aggarwal \& Padhan (2017) menegaskan rasio financial leverage memiliki pengaruh signifikan terhadap nilai perusahaan sehingga menyoroti bahwa pentingnya struktur modal pada nilai perusahaan. Aggarwal \& Padhan (2017) menegaskan rasio financial leverage memiliki pengaruh signifikan terhadap nilai perusahaan sehingga menyoroti bahwa pentingnya struktur modal pada nilai perusahaan.

Financial leverage direpresentasikan dalam proses penggunaan hutang (Borrowing) dalam struktur keuangan atau pinjaman yang surplusnya dapat diinvestasikan kembali untuk memperoleh pendapatan lebih dengan pengukuran rasio hutang atas ekuitas. Penggunaan financial leverage mampu meningkatkan nilai perusahaan karena dalam perhitungan pajak, bunga yang dikenakan akibat penggunaan hutang dikurangkan dahulu, sehingga perusahaan memperoleh keringanan pajak (Rudangga \& Sudiarta, 2016). Pribadi (2018) berpendapat bahwa nilai perusahaan sebenarnya tidak hanya bergantung pada tingkat hutang perusahaan tetapi juga memperhatikan skala perusahaan atau size.

Size merupakan salah satu faktor yang dapat memengaruhi nilai perusahaan (Purwanti, 2020). Perusahaan yang memiliki ukuran besar cenderung mampu menghadapi persaingan ekonomi karena mereka memiliki manajemen atau kontrol yang lebih baik, sehingga membuat mereka tidak rentan terhadap fluktuasi ekonomi. Studi empiris telah mengungkapkan bahwa ukuran perusahaan dan nilai perusahaan memberikan pengaruh positif (Al-Slehat, 2020; Aggarwal \& Padhan, 2017; Rudangga \& Sudiarta, 2016; dan Indriyani, 2017). Hal ini memperlihatkan size yang tinggi menyebabkan 
nilai perusahaan semakin tinggi pula. Akibatnya, perusahaan yang besar cenderung memiliki kondisi yang lebih stabil.

Namun, hasil penelitian Purwanti (2020); Zuhroh (2019); Purwohandoko (2017); Setiadharma \& Machali (2017) tidak mendukung pernyataan tersebut. Karena, perusahaan besar tidak selamanya dapat meningkatkan nilai perusahaan. Atmaja (2008) berpendapat bahwa size merupakan jumlah aset yang dimiliki perusahaan. Aset perusahaan merupakan aspek yang berkaitan dengan sumber daya perusahaan, biasa disebut struktur aset.

Struktur aset merupakan semua sumber daya dan harta yang dimiliki perusahaan, digunakan untuk menjalankan kegiatan perusahaaan. Menurut Setiadharma \& Machali (2017) menemukan struktur aset adalah faktor dalam menentukan nilai perusahaan. Hal ini tetap konsisten bahwa struktur aset memiliki pengaruh positif dan signifikan terhadap nilai perusahaan (AlSlehat, 2020) sehingga ketika struktur aset meningkat maka nilai perusahaan akan meningkat pula. Itu semua dapat terjadi apabila manajerial perusahaan berjalan dengan baik dan optimal. Artinya, corporate governance memiliki peranan penting dalam meningkatkan nilai perusahaan (Obradovich \& Gill, 2012).

Corporate governance dalam konteks penelitian ini mendefinisikan dan mempraktikkan cara yang berbeda dengan menyesuaikan pada kekuatan relatif dari pemilik perusahaan, manajer dan penyedia modal. Hal ini memerlukan prosedur, adat istiadat, hukum dan kebijakan yang memengaruhi cara perusahaan diarahkan, dikelola dan dikedalikan (Craig, 2005). Karenanya, corporate governance sangat diperlukan dan erat kaitannya dalam meningkatkan nilai perusahaan. Obradovich \& Gill (2012) dan Nayli \& Mardani (2018) berpendapat bahwa corporate governance berpengaruh positif terhadap nilai perusahaan yang diukur dengan CEO duality.

Nurhaiyani (2018), K. Dewi et al., (2019) dan Rulimo et al., (2019), mendukung hasil penelitian sebelumnya dengan melihat bahwa corporate governance yang baik dapat menggunakan komisaris independen untuk operasi bisnis perusahaan yang maksimal. Namun, tidak konsisten dengan hasil penelitian Putra (2016) yang menunjukkan pengaruh negatif antara proporsi komisaris independen dan nilai perusahaan. Penelitian ini mencoba meyakinkan hal tersebut dengan mengukur corporate governance menggunakan $C E O$ duality dan proporsi komisaris independen. Karena, CEO duality dan komisaris independen diharapkan dapat memengaruhi kemampuan perusahaan untuk bertindak sesuai dengan kepentingan perusahaan sehingga dapat meningkatkan nilai perusahaan secara maksimum.

Penelitian ini bertujuan untuk menguji faktor-faktor yang memengaruhi nilai perusahaan karena ketidakkonsistenan pada penelitianpenelitian sebelumnya. Penelitian ini menggunakan variabel financial leverage, size, struktur aset, corporate governance dan nilai perusahaan yang diproksikan dengan Price to Book Value (PBV). Perbandingan ini dipergunakan untuk memperkirakan tingkat harga saham pada suatu perusahaan sehingga dapat diartikan apabila mengalami penurunan pada harga saham suatu perusahaan maka tingkat PBV mengalami undervalued. 
Akibat kurangnya nilai PBV menyebabkan kualitas serta kemampuan fundamental emiten akan menurun, begitu pula sebaliknya (Permatasari, Isharijadi \& Wihartanti, 2020)

Sampel penelitian dilakukan pada perusahaan manufaktur yang terdaftar di Jakarta Islamic Index (JII) dengan periode tahun pengamatan 2015 hingga 2019, karena terdapat kasus mengenai penurunan nilai tukar rupiah terhadap dolar Amerika Serikat yang terjadi pada tahun 2015. Berdasarkan data Bank Indonesia, nilai tukar rupiah terhadap mata uang Amerika Serikat mencapai Rp 13.286 rupiah per US\$1 sehingga berdampak pada kerugian sektor riil Indonesia terutama industri. Unsur kebaruan dalam penelitian ini adalah penggunaan sampel penelitian hingga tahun 2019, dimana tahun tersebut merupakan tahun dimana perusahaan berjalan secara normal sebelum terdampak pandemi COVID19, sehingga dapat dibandingkan secara normal dengan tahun-tahun sebelumnya. Penggunaan variabel CEO duality dalam unsur Good Corporate Governance diharapkan mampu untuk meningkatkan nilai perusahaan. Dengan penerapan CEO Duality memiliki kelebihan dalam menekan agency cost serta menurunkan tingkat asymetri informasi.

\section{TELAAH TEORITIS}

\subsection{TEORI SIGNALLING}

Istilah sinyal dalam teori signalling diartikan sebagai tindakan yang diambil oleh manajemen perusahaan yang memberikan petunjuk kepada investor mengenai bagaimana cara pandang manajemen terhadap prospek perusahaan (Brigham Eugene \& Joe, 2006). Teori signalling adalah teori yang menerangkan suatu tindakan yang diambil manajemen perusahaan dengan memberi petunjuk kepada investor tentang cara manajemen memandang prospek perusahaan. Dalam penelitian ini, teori signalling ini digunakan untuk menjelaskan hubungan antara manajemen dengan investor maupun stakeholder dimana informasi yang disampaikan oleh perusahaan berupa financial leverage, total aset, struktur aset dan penerapan good corporate governance akan memberikan sinyal bagi para pelaku pasar modal untuk melakukan pembelian terhadap saham perusahaan.

\subsection{TEORI AGENSI}

Teori agensi menjelaskan masalah principal-agent dalam pemisahan kepemilikan dan pengendalian perusahaan (Jensen \& Meckling, 1976) antara pemasok modal yang berbeda (Smith \& Warner, 1979) dan pemisahan dalam menanggung risiko, pengambilan keputusan dan fungsi kontrol di perusahaan (E. F. Fama \& Jensen, 1983). Teori agensi memiliki asumsi bahwa setiap individu semata-mata hanya termotivasi oleh kepentingan dirinya sendiri sehingga menimbulkan konflik kepentingan antara principal dan agent. Jika individu bertindak mementingkan diri sendiri, maka akan menyebabkan konflik. 
Teori agency memiliki dua mekanisme yaitu mekanisme internal dan eksternal (Babatunde \& Olaniran, 2009), Mekanisme internal dalam good corporate governance terdiri dari ownership structure, board structure, kompensasi manajerial, transparansi keuangan, dan pengungkapan informasi yang berimbang. Mekanisme eksternal adalah teknik berbasis pasar yang didesain untuk menguatkan struktur internal dalam tata kelola, yang diwujudkan dalam aturan dan perundang-undangan untuk menciptakan efisiensi bagi proses operasional perusahaan, baik dalam lingkungan internal maupun eksternal perusahaan (OECD, 2005).

Mekanisme yang digunakan dalam penelitian ini adalah mekanisme internal yaitu transparansi keuangan, CEO Duality dan struktur dewan komisaris independen. Transparansi keuangan ini merupakan bentuk akuntabilitas perusahaan terhadap para pemegang saham dan masyarakat dalam mempertanggungjawabkan operasional perusahaan, sedangkan struktur dewan komisaris independen yang merupakan amanat UU No. 40 Tahun 2007 yang diangkat berdasarkan keputusan RUPS dari pihak yang tidak terafiliasi dengan pemegang saham utama, anggota Direksi dan/atau anggota Dewan Komisaris lainnya untuk menjamin independensi pengawasan terhadap perusahaan.

\subsection{NILAI PERUSAHAAN}

Nilai perusahaan tercermin pada harga pasar saham.Semakin tinggi harga saham, semakin tinggi nilai perusahaan (E. Fama, 1980). Menurut Mardiyanto (2009) nilai perusahaan adalah nilai sekarang dari serangkaian arus kas masuk yang akan dihasilkan perusahaan pada masa mendatang. Ketika nilai perusahaan meningkat berarti publik menilai kinerja dan performa perusahaan tersebut memiliki prospek yang baik, serta tujuan utama perusahaan dapat tercapai. Oleh karena itu, nilai perusahaan sangat penting dalam mengukur kinerja perusahaan yang dapat memengaruhi persepsi para calon investor terhadap tingkat keberhasilan perusahaan yang sering dikaitkan dengan harga saham.

\subsection{FINANCIAL LEVERAGE DAN NILAI PERUSAHAAN}

Onyenwe \& Glory (2017) mengungkapkan bahwa financial leverage adalah ukuran berapa banyak perusahaan menggunakan hutang dan ekuitas untuk membiayai asetnya. Financial leverage berbentuk pinjaman atau pinjaman lain (hutang) yang akan diinvestasikan kembali dengan maksud untuk mendapatkan tingkat pengembalian yang lebih besar daripada biaya bunga. Financial leverage adalah penggunaan dana pihak ketika dalam pembiayaan untuk meningkatkan laba operasi dan pajak, yang merupakan rasio pinjaman terhadap total kewajiban.

Temuan oleh Modigliani dan Miller (1958) menjelaskan untuk mempertimbangkan antara besarnya risiko yang timbul akibat penggunaan hutang dengan tingkat return yang didapatkan karena manfaat dari hutang tersebut, maka manajer harus melakukan penilaian trade-off antara risiko dan return. Penentuan kebijakan hutang berkaitan dengan struktur modal karena 
hutang merupakan salah satu komposisi dalam struktur modal. Karena itu, struktur modal dapat memengaruhi nilai saham perusahaan (Barakat, 2014).

Penelitian mengenai financial leverage telah dilakukan Aggarwal \& Padhan, (2017) dan Rudangga \& Sudiarta (2016) menunjukkan hasil yang positif dan signifikan antara financial leverage dan nilai perusahaan. Namun, penelitian tersebut tidak konsisten dengan penelitian Ibrahim \& Isiaka, (2020), Al-Slehat (2020), Fajaria \& Isnalita (2018) yang menyatakan bahwa financial leverage memiliki pengaruh negatif terhadap nilai perusahaan dan tidak ada pengaruh signifikan antara financial leverage dengan nilai perusahaan (Barakat, 2014). Artinya, perusahaan dalam mendanai aktivitasnya cenderung menggunakan modal sendiri (internal financing) yang berasal dari laba ditahan dan modal saham daripada menggunakan hutang.

Kecukupan dana yang dimiliki perusahaan untuk membiayai aktivanya yang diperoleh dari modal sendiri membuat perusahaan mengurangi dalam proporsi hutang. Penggunaan hutang yang berlebihan akan mengurangi manfaat yang diterima atas penggunaan hutang karena manfaat yang diterima tidak sebanding dengan biaya yang ditimbulkan, sehingga proporsi hutang yang rendah dapat meningkatkan nilai perusahaan dan sebaliknya peningkatan hutang dapat menurunkan nilai perusahaan hal ini dibuktikan oleh Ibrahim \& Isiaka, (2020), Al-Slehat (2020), Fajaria \& Isnalita (2018) yang menyatakan bahwa hutang yang tinggi menurunkan nilai perusahaan, maka peneliti mengusulkan hipotesis:

H1: Financial leverage memiliki pengaruh negatif terhadap nilai perusahaan

\subsection{SIZE DAN NILAI PERUSAHAAN}

Ukuran perusahaan adalah besar atau kecilnya suatu perusahaan yang menggambarkan nilai total aset, jumlah penjualan, rata-rata penjualan dan rata-rata total aset (Oktaviani et al., 2019). Semakin tinggi total aset dan penjualan perusahaan menunjukkan perputaran dana di perusahaan, sehingga jika total aset dalam tingkatan tinggi menyebabkan semakin besar modal yang diinvestasikan perusahaan. Atmaja (2008) mengungkapkan bahwa ukuran perusahaan merupakan jumlah aset yang dimiliki oleh suatu perusahaan. Ukuran perusahaan menjadi salah satu faktor yang dipertimbangkan investor untuk berinvestasi.

Setiap perusahaan mempunyai ukuran yang berbeda-beda. Perusahaan besar dapat dengan mudah mengakses pasar modal. Kemudahan untuk mengakses ke pasar modal berarti perusahaan memiliki fleksibilitas dan kemampuan untuk memunculkan dana yang lebih besar. Sehingga, kemudahan tersebut ditangkap oleh investor sebagai sinyal positif dan prospek yang baik sehingga size bisa memberikan pengaruh yang positif terhadap nilai perusahaan (Sobirin, 2007).

Hasil penelitian yang dilakukan oleh Al-Slehat (2020), Aggarwal \& Padhan, (2017), Rudangga \& Sudiarta (2016), menyatakan bahwa terdapat pengaruh positif antara size terhadap nilai perusahaan dan konsisten pula secara simultan pengaruh size dengan nilai perusahaan (Indriyani, 2017). Temuan tersebut memperlihatkan bahwa size yang tinggi menyebabkan nilai 
perusahaan semakin tinggi pula. Hal ini disebabkan karena perusahaan yang besar cenderung memiliki kondisi yang lebih stabil.

Kondisi yang stabil menjadi penyebab atas naiknya harga saham perusahaan di pasar modal, di mana investor akan memiliki ekspektasi yang besar terhadap perusahaan. peningkatan permintaan saham perusahaan akan dapat memacu pada peningkatan harga saham di pasar modal. Peningkatan tersebut menunjukkan bahwa perusahaan memiliki nilai yang lebih besar. Namun, penelitian Purwanti (2020), Zuhroh (2019), Purwohandoko (2017), Setiadharma \& Machali (2017) tidak konsisten. Sehingga, perusahaan berskala besar tidak selamanya dapat meningkatkan nilai perusahaan. Oleh karena itu, peneliti mengusulkan hipotesis:

$\mathrm{H} 2$ : Size memiliki pengaruh positif terhadap nilai perusahaan.

\subsection{STRUKTUR ASET DAN NILAI PERUSAHAAN}

Struktur aset merupakan salah satu aspek yang berkaitan dengan sumber daya perusahaan, seperti aset tetap dan aset lancar. Keduanya adalah kepemilikan perusahaan pada waktu tertentu untuk periode tertentu yang dapat diukur melalui persamaan persentase aset lancar terhadap total aset, aset tetap terhadap total aset dan rasio aset lainnya terhadap total aset. Al Ani (2014) dan Ukhriyawati et al., (2017) mengungkapkan bahwa struktur aset merupakan sekumpulan aset berwujud perusahaan dalam membangun dan memperluas proporsi serta menggunakannya dalam operasi perusahaan, sehingga aset berwujud dijadikan sebagai jaminan perusahaan untuk mendapatkan pembiayaan hutang dari bank.

Struktur aset menggambarkan besarnya aset yang dapat dijaminkan perusahaan ketika perusahaan melakukan pinjaman kepada kreditor. Struktur aset merupakan proporsi aset tetap yang dimiliki oleh perusahaan (Mawikere \& Rate, 2015). Komposisi aset tetap menentukan nilai perusahaan tertentu. Sebagian besar perusahaan dengan keuangan yang stabil memiliki nilai investasi yang tinggi dalam hal aset tetap. Ketika aset tersebut dimanfaatkan secara optimal oleh staff yang kompeten, maka akan dapat meingkatkan return perusahaan sehingga dapat berpengaruh pada pertumbuhan nilai perusahaan Nyamasege et al. (2014) dalam hasil temuan Pribadi (2018).

Pernyataan tersebut didukung oleh Al-Slehat (2020), Setiadharma \& Machali (2017) mengungkapkan bahwa struktur aset memiliki pengaruh signifikan dan pengaruh positif terhadap nilai perusahaan sehingga jika struktur aset meningkat maka nilai perusahaan akan meningkat juga. Oleh karena itu, peneliti mengusulkan hipotesis:

H3: Struktur aset memiliki pengaruh positif terhadap nilai perusahaan

\subsection{CORPORATE GOVERNANCE DAN NILAI PERUSAHAAN}

Corporate governance merupakan sistem di mana perusahaan diarahkan dan dikendalikan. Hal ini menentukan distribusi hak dan tanggung jawab di antara partisipan yang berbeda dalam perusahaan, seperti dewan, manajer, pemegang saham dan pemangku kepentingan lainnya, dan menjelaskan aturan dan prosedur untuk membuat keputusan perihal perusahaan. Selain itu, 
corporate governance menyediakan struktur di mana tujuan perusahaan ditetapkan dan memantau kinerja apa saja yang dicapai (OECD, 1999; Okiro et al., 2015). Tujuan penting dari corporate governance adalah untuk memastikan akuntabilitas dan transparansi bagi mereka yang terlibat dalam implementasi kebijakan organisasi melalui mekanisme yang akan mengurangi konflik agen utama. Keasey dan Wright (1993) mendefinisikan corporate governance sebagai kerangka kerja untuk pemantauan yang efektif, regulasi dan pengendalian perusahaan yang memungkinkan mekanisme alternatif internal dan eksternal untuk mencapai tujuan yang ditetapkan.

Fatoni \& Sulhan (2020) mengatakan bahwa pengelolaan perusahaan juga memengaruhi nilai perusahaan. Masalah corporate governance muncul karena terjadinya pemisahan antara kepemilikan dan pengendalian perusahaan. Pemisahan ini didasarkan pada agency theory di mana manajemen cenderung akan meningkatkan keutungan pribadinya daripada tujuan perusahaan. Nilai suatu perusahaan dapat dikatakan baik apabila tata kelola perusahaan dilaksanakan dengan baik. Karenanya, corporate governance sangat diperlukan dan erat kaitannya dalam meningkatkan nilai perusahaan.

Obradovich \& Gill (2012) menyatakan bahwa corporate governance berpengaruh positif dan signifikan terhadap nilai perusahaan, diukur dengan CEO duality, komite audit, kepemilikan institusional. Nayli \& Mardani (2018) mendukung hasil penelitian tersebut dengan mengindikasikan $C E O$ duality sebagai ukuran corporate governance. Oleh karena itu, peneliti mengusulkan hipotesis:

H4a: CEO duality memiliki hubungan positif terhadap nilai perusahaan

Rulimo et al., (2019) dan K. Dewi et al., (2019) menyatakan bahwa komisaris independen memiliki pengaruh positif dan signifikan terhadap nilai perusahaan diproksikan dengan Tobin's Q. Nurhaiyani (2018) memperkuat hasil penelitian tersebut dengan proporsi komisaris independen. Hal ini menunjukkan bahwa CEO duality dan komisaris independen dapat memengaruhi kemampuan perusahaan untuk bertindak independen sesuai kepentingan perusahaan, sehingga peneliti mengusulkan hipotesis:

H4b: Proporsi komisaris independen memiliki pengaruh positif terhadap nilai perusahaan

\section{METODE PENELITIAN}

Penelitian ini menggunakan pendekatan kuantitatif dengan mengumpulkan data melalui data sekunder yang diperoleh dari laporan keuangan tahunan. Periode tahun pengamatan penelitian ini adalah 2015 hingga 2019. Pemilihan sampel dilakukan menggunakan metode purposive sampling, yaitu pemilihan sampel berdasarkan karakteristik tertentu dengan tujuan agar diperoleh sampel yang representatif sesuai dengan penelitian yang akan dilakukan. Karakteristik yang digunakan adalah sebagai berikut: 
a. Perusahaan dalam sektor manufaktur yang terdaftar di Jakarta Islamic Index (JII) periode 2015-2019.

b. Perusahaan yang menerbitkan laporan keuangan tahunan (annual report) dan selama periode 2015-2019 secara berturut-turut.

c. Perusahaan dalam sektor manufaktur yang menggunakan mata uang rupiah.

Penelitian ini menggunakan variable dependen berupa nilai perusahaan dan variable independent berupa Financial leverage, size, struktur asset, dan corporate governance. Nilai perusahaan diukur dengan Price to Book Value (PBV). Proksi ini dipilih karena menurut Purwohandoko (2017) nilai perusahaan dapat didefinisikan sebagai nilai wajar perusahaan yang menggambarkan persepsi investor terhadap emiten yang bersangkutan. Penelitian ini menggunakan rumus:

$$
\text { Price Book Value }=\frac{\text { Harga Pasar Per Saham }}{\text { Nilai Buku }}
$$

Selanjutnya, Financial leverage mengacu pada sejauh mana struktur modal perusahaan menggambarkan perbandingan total hutang terhadap total ekuitas. Pengukuran variabel penelitian ini mengacu pada penelitian (AlSlehat, 2020).

$$
\text { Debt to Equity Ratio }=\frac{\text { Total Hutang }}{\text { Total Ekuitas }}
$$

Secara umum, size diukur dengan besarnya total aset yang dimiliki karena nilai total aset umumnya sangat besar dibandingkan variabel keuangan lainnya. Penulis menghitung size mengacu pada penelitian yang dilakukan Fajaria \& Isnalita (2018), dengan nilai logaritma natural dari total aset.

$$
\text { Size }=\text { Ln (Total Aset) }
$$

Salah satu aspek yang berkaitan dengan sumber daya perusahaan yang menggambarkan struktur aset adalah aset tetap dan aset lancar. Penelitian ini mengacu pada pengukuran struktur aset yang dilakukan Al-Slehat (2020).

$$
\text { Struktur Aset }=\frac{\text { Aset Tetap }}{\text { Total Aset }}
$$

Corporate governance diartikan sebagai mekanisme, proses dan hubungan dimana terdapat organisasi yang memantau dan mengarahkan suatu perusahaan (Kuhatlunga et al., 2017). Dalam penerapannya corporate governance menggunakan proporsi komisaris independen dan CEO duality sebagai indikator dalam penelitian ini. Pada dasarnya $C E O$ duality berkaitan dengan situasi di mana CEO dalam suatu perusahaan menjalankan tugas yang sama dengan chairman of board (dewan komisaris) dalam suatu perusahaan. Pengukuran $C E O$ duality dilakukan dengan cara variabel dummy. Penulis akan menggunakan nilai 1 untuk perusahaan yang memiliki CEO duality dan nilai 0 untuk perusahaan yang tidak memiliki CEO duality (Kuhatlunga et al., 2017). Selanjutnya, komisaris independen adalah anggota dewan komisaris 
yang tidak terafiliasi dengan manajemen, anggota dewan komisaris lainnya dan pengendali pemegang saham. Komisaris independen dapat diperhitungkan menggunakan rumus dibawah ini (Rulimo et al., 2019).

$$
\text { Komisaris Independen }=\frac{\text { Jumlah Komisaris Independen }}{\text { Jumlah Anggota Dewan Komisaris }}
$$

\subsection{UJI ASUMSI KLASIK}

Sebelum melakukan analisis regesi, perlu dilakukan pengujian asumsi klasik. Hal ini dilakukan agar data sampel yang diolah dapat benar-benar mewakili populasi secara keseluruhan. Beberapa pengujian asumsi pada penelitian ini adalah sebagai berikut:

\subsection{UJI MULTIKOLINIERITAS}

Uji multikolinieritas merupakan pengujian yang perlu dilakukan pada saat regresi lebih dari satu variabel independen. Uji multikolinieritas bertujuan untuk menguji apakah pada model regresi ditemukan adanya korelasi antar variabel independen. Model yang baik seharusnya tidak ada korelasi antar variabel independen (Ghozali, 2013). Dalam rangka mendeteksi adanya gejala multikolinieritas dalam regresi pada model penelitian, maka dapat menggunakan pedoman sebagai berikut:

a. Jika nilai tolerance $>0,10$ maka data tersebut tidak terjadi multikolinieritas dan jika nilai VIF $<10,00$ maka data tersebut tidak terjadi multikolinieritas.

b. Jika nilai tolerance $<0,10$ maka data tersebut terjadi multikolinieritas dan jika nilai VIF > 10,00 maka data tersebut terjadi multikolinieritas.

\subsection{UJI AUTOKORELASI}

Uji autokorelasi bertujuan menguji apakah dalam model regresi linier ada korelasi antara kesalahan pengganggu pada periode $\mathrm{t}$ dengan kesalahan pengganggu pada periode t-1 (periode sebelumnya). Autokorelasi muncul karena observasi yang berurutan sepanjang waktu berkaitan satu sama lainnya. Model regresi yang baik adalah regresi yang bebas dari autokorelasi. Salah satu cara yang digunakan untuk mendeteksi adanya autokorelasi ini adalah uji Durbin Waston (DW) (Suharyadi \& Purwanto, 2017). Menurut Ghozali (2013) untuk mendeteksi ada tidaknya autokorelasi secara umum dapat diambil kesimpulan sebagai berikut:

a. Jika d $>$ Du berarti tidak terdapat autokorelasi positif

b. Jika $\mathrm{d}<(4-\mathrm{dU})$ berarti tidak terdapat autokorelasi negatif.

c. Jika dU $<\mathrm{d}<(4-\mathrm{dU})$ berarti tidak terdapat autokorelasi. 


\subsection{UJI HETEROSKEDASTISITAS}

Uji heteroskedastisitas bertujuan untuk menguji apakah dalam model regresi terjadi ketidaksamaan varian nilai residual satu pengamatan ke pengamatan yang lain. Jika varian nilai residual dari satu pengamatan ke pengamatan lain berbeda, maka disebut dengan heteroskedastisitas dan jika tetap disebut dengan homokedastisitas (Suharyadi \& Purwanto, 2017). Analisis uji heteroskedastisitas dapat menggunakan uji glejser.

Uji glejser mengusulkan untuk meregres nilai absolut residual terhadap variabel dependen. Menurut Ghozali (2013) mengatakan bahwa uji glejser merupakan salah satu uji statistik yang lebih menjamin dalam keakuratan hasil. Model regresi yang baik adalah tidak terjadi heteroskedastisitas

\subsection{ANALISIS REGRESI LINEAR BERGANDA}

Model analisis regresi linear berganda dalam penelitian ini adalah:

$$
Y=\alpha+\beta_{1} X_{1}+\beta_{2} X_{2}+\beta_{3} X_{3}+\beta_{4} X_{4}+e
$$

$\begin{array}{cl}\text { Keterangan: } & \\ \mathrm{Y} & \text { : Nilai Perusahaan } \\ \mathrm{X}_{1} & \text { : Financial Leverage } \\ \mathrm{X}_{2} & : \text { Size } \\ \mathrm{X}_{3} & : \text { Struktur Aset } \\ \mathrm{X}_{4} & : \text { Corporate Governance } \\ \alpha & : \text { Konstanta } \\ \beta & : \text { Koefisien Regresi } \\ \mathrm{e} & : \text { Error }\end{array}$

\section{HASIL DAN DISKUSI}

Sampel yang digunakan dalam penelitian ini adalah 10 perusahaan dengan periode tahun pengamatan 2015 sampai dengan 2019 sehingga total keseluruhan sampel yang digunakan dalam penelitian ini sebanyak 50. Tabel dibawah ini menunjukkan hasil pengujian variabel dalam penelitian secara statistik deskriptif:

Tabel 1. Hasil Statistik Deskriptif

\begin{tabular}{lccccc}
\hline & N & Minimum & Maximum & Mean & $\begin{array}{c}\text { Std. } \\
\text { Deviation }\end{array}$ \\
\hline DER & 50 & 0,153 & 2,909 & 0,96492 & 0,753177 \\
SZ & 50 & 1,099 & 5,864 & 3,38344 & 1,066326 \\
SA & 50 & 0,079 & 0,569 & 0,30692 & 0,136287 \\
CD & 50 & 0,000 & 1,000 & 0,18000 & 0,388088 \\
KI & 50 & 0,286 & 0,800 & 0,45244 & 0,151167 \\
PBV & 50 & 1,003 & 82,444 & 8,94114 & 18,329712 \\
Valid N (listwise) & 50 & & & \\
\hline \multicolumn{5}{c}{ Sumber: Output SPSS (2021) } \\
\end{tabular}


Sebelum melakukan uji hipotesis, peneliti melakukan uji asumsi klasik. Hasil Uji Multikolinearitas pada Tabel 2. menunjukkan bahwa nilai Tolerance antar variabel independen lebih besar dari 0,10 dan nilai VIF tidak lebih besar dari 10,00. Hal ini menunjukkan bahwa tidak terdapat multikolinieritas atau hubungan antar variabel independen dalam penelitian ini.

Tabel 2. Uji Multikolinieritas

\begin{tabular}{lcc}
\hline & Tolerance & VIF \\
\hline DER & 0,790 & 1,265 \\
SZ & 0,697 & 1,435 \\
SA & 0,612 & 1,634 \\
CD & 0,833 & 1,201 \\
KI & 0,760 & 1,315 \\
\hline
\end{tabular}

Sumber: Output SPSS (2021)

Selanjutnya, Uji Autokorelasi pada tabel 3 diukur menggunakan Durbin-Watson dengan signifikansi sebesar 5\%, maka dapat ditentukan bahwa nilai dU adalah 1,7214 dan nilai $(4-\mathrm{dU}=2,2786)$. Sehingga nilai $\mathrm{dU}$ $<\mathrm{d}<(4-\mathrm{dU})$ adalah 1,7214 < 1,905 < 2,2786. Dapat disimpulkan bahwa dalam penelitan ini bebas dari adanya autokorelasi. Demikian juga dengan uji heterokesdastisitas pada tabel 4, tidak ada satupun variabel independen yang signifikan secara statistik memengaruhi variabel dependen nilai absolut residual sehingga dapat disimpulkan bahwa model regresi tidak mengandung adanya heteroskedastisitas.

Tabel 3. Uji Autokorelasi

\begin{tabular}{cc}
\hline Model & Durbin-Watson \\
\hline 1 & $1,905^{\mathrm{a}}$ \\
\hline
\end{tabular}

a. Predictors: (Constant), KI, SZ, CD, DER, SA

Sumber: Output SPSS (2021)

Tabel 4. Uji Heteroskedastisitas

\begin{tabular}{|l|c|c|c|c|c|}
\hline \multicolumn{2}{|c|}{ Unstandardized Coefficients } & $\begin{array}{c}\text { Standardized } \\
\text { Coefficients }\end{array}$ & \multirow{2}{*}{$\mathrm{t}$} & \multirow{2}{*}{ Sig. } \\
\cline { 1 - 4 } & B & $\begin{array}{c}\text { Std. } \\
\text { Error }\end{array}$ & Beta & & \\
\hline (Constant) & 1,826 & 2,479 & & 0,736 & 0,465 \\
\hline DER & 1,089 & 0,630 & 0,267 & 1,728 & 0,091 \\
\hline SZ & $-0,281$ & 0,474 & $-0,097$ & $-0,593$ & 0,556 \\
\hline SA & 2,973 & 3,956 & 0,132 & 0,752 & 0,456 \\
\hline CD & $-1,243$ & 1,191 & $-0,157$ & $-1,044$ & 0,302 \\
\hline KI & 4,067 & 3,199 & 0,200 & 1,271 & 0,210 \\
\hline
\end{tabular}

Sumber: Output SPSS (2021) 
Pengujian selanjutnya adalah uji hipotesis. Tabel dibawah ini menunjukkan hasil regresi berganda dalam penelitian ini.

Tabel 5. Hasil Analisis Regresi Berganda

\begin{tabular}{lrrc}
\hline & \multicolumn{1}{c}{ Coeff } & \multicolumn{1}{c}{-Stat } & Sig \\
\hline (Constant) & $-54,669$ & $-11,316$ & 0,000 \\
DER & 12,056 & 9,824 & 0,000 \\
SZ & 2,638 & 2,858 & 0,006 \\
SA & 69,357 & 8,998 & 0,000 \\
CD & 6,312 & 2,720 & 0,009 \\
KI & 45,592 & 7,314 & 0,000 \\
$R$ Square & 0,912 & & \\
Adjusted R Square & 0,902 & & \\
F-Stat & 90,712 & & \\
Sig. & 0,000 & & \\
\hline
\end{tabular}

Sumber: Data diolah (2021)

Berdasarkan hasil analisis regresi berganda dapat disimpulkan bahwa hipotesis yang menyatakan financial leverage memiliki pengaruh negatif terhadap nilai perusahaan ditolak. Hasil pengujian ini tidak sejalan dengan penelitian Ibrahim \& Isiaka (2020), Al-Slehat (2020), Fajaria \& Isnalita (2018) yang membuktikan bahwa financial leverage memiliki pengaruh negatif terhadap nilai perusahaan. Namun, hasil ini konsisten dengan penelitian Aggarwal \& Padhan (2017) yang membuktikan bahwa financial leverage berpengaruh positif terhadap nilai perusahaan. Penelitian ini juga didukung oleh Rudangga \& Sudiarta (2016) yang menjelaskan bahwa perusahaan mampu melunasi hutangnya, sehingga dapat dikatakan bahwa perusahaan dalam sektor manufaktur sudah melakukan kinerja terbaik untuk menciptakan nilai perusahaan yang semakin meningkat.

Grafik 1. Financial Leverage dan Price to Book Value

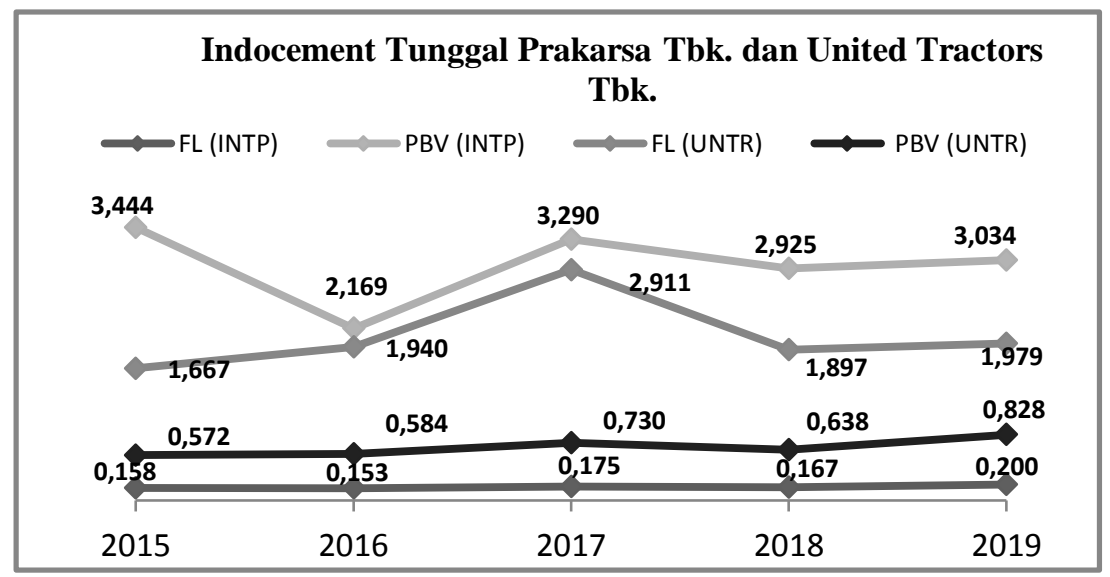


Temuan ini sesuai dengan teori Modigliani dan Miller (1958) yang menyatakan bahwa besarnya risiko yang timbul akibat penggunaan hutang dengan tingkat return yang didapatkan karena manfaat dari hutang tersebut. Hal ini membuktikan bahwa dengan mekanisme internal corporate governance mampu mendorong peningkatan nilai perusahaan sebagai bentuk tanggung jawab terhadap principal. Financial Leverage dan nilai perusahaan dalam perusahaan dapat dilihat pada Grafik 1.

Berdasarkan Grafik 1 dapat diketahui bahwa financial leverage perusahaan Indocement Tunggal Prakarsa Tbk. mengalami penurunan pada tahun 2016 diikuti dengan penurunan nilai perusahaan yang diproksikan oleh Price to Book Value. Pada tahun 2017 financial leverage perusahaan tersebut meningkat disertai dengan meningkatnya nilai perusahaan, begitu pula tahun berikutnya. Disisi lain, perusahaan United Tractors Tbk. juga menunjukkan hal serupa bahwa tinggi rendahnya financial leverage perusahaan diikuti oleh peningkatan dan penurunan Price to Book Value yang diperlihatkan oleh Grafik 1 Oleh sebab itu, penelitian ini membuktikan bahwa nilai perusahaan meningkat ketika financial leverage perusahaan tinggi dan sebaliknya menurunkan nilai perusahaan ketika financial leverage perusahaan rendah.

Hasil lain menunjukkan bahwa size memiliki pengaruh positif terhadap nilai perusahaan diterima. Hasil pengujian ini sejalan dengan penelitian Al-Slehat (2020), Aggarwal \& Padhan (2017) dan Rudangga \& Sudiarta (2016) yang membuktikan bahwa terdapat pengaruh positif antara size dan nilai perusahaan. Perusahaan berskala besar dapat menunjukkan kondisi perusahaan sedang mengalami perkembangan dan menjadikan sinyal yang baik bagi investor. Investor akan merespon secara positif sehingga mengakibatkan kenaikan harga saham (Sofia \& Akhmadi, 2018). Hal tersebut sesuai dengan signalling theory yang menjelaskan bahwa ukuran perusahaan yang besar dapat memberikan sinyal bagi investor yang menaruh perhatian kepada perusahaan. Dengan demikian size menjadi salah satu faktor yang dipertimbangkan investor untuk berinvestasi. Berikut adalah grafik yang menandakan adanya pengaruh antara size dan nilai perusahaan.

Grafik 2. Size dan Price to Book Value

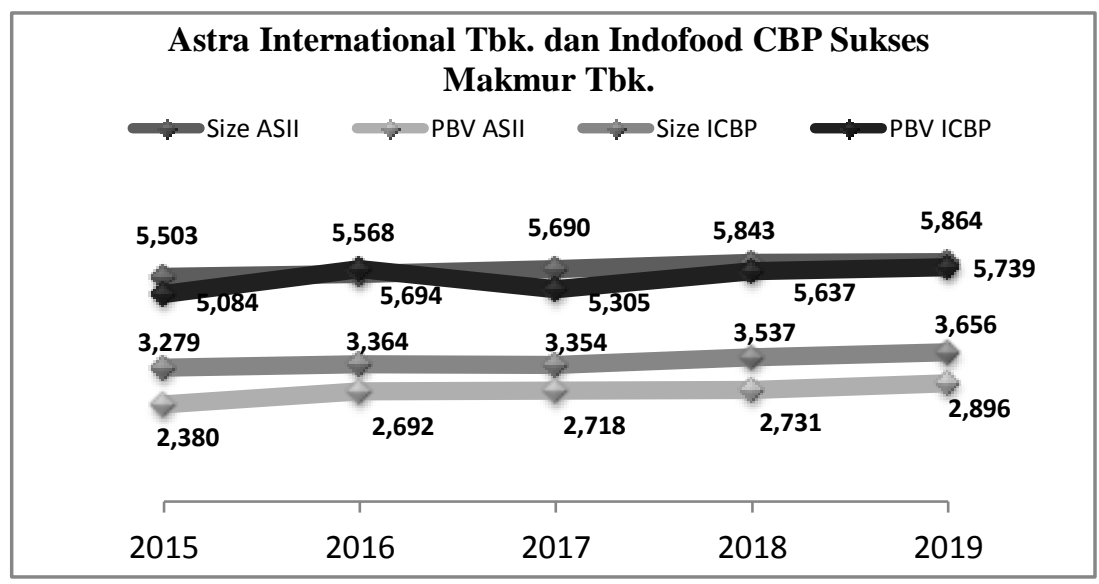


Berdasarkan Grafik 2 dapat diketahui bahwa sejak tahun 2016 sampai dengan 2019 size perusahaan Astra International Tbk. mengalami kenaikan terus-menerus diikuti dengan meningkatnya nilai perusahaan, terkecuali tahun 2017 karena penurunan size menandakan Price to Book Value rendah. Disisi lain, size perusahaan Indofood CBP Sukses Makmur Tbk. juga menunjukkan kenaikan disertai dengan tingginya Price to Book Value dari tahun ke tahun, hanya saja pada tahun 2018 terjadi penurunan size yang menandakan rendahnya Price to Book Value sehingga dikatakan bahwa nilai perusahaan tahun tersebut menurun. Penelitian ini membuktikan bahwa perusahaan yang besar dianggap memiliki "nilai" yang lebih besar. Selain itu, perusahaan yang besar cenderung memiliki kondisi yang lebih stabil sehingga dapat menaikkan harga saham perusahaan di pasar modal.

Selanjutnya, hasil menunjukkan bahwa struktur aset memiliki pengaruh positif terhadap nilai perusahaan diterima. Hasil pengujian ini mendukung penelitian Al-Slehat (2020) dan Setiadharma \& Machali (2017) yang membuktikan bahwa struktur aset memiliki pengaruh signifikan dan memiliki arah positif terhadap nilai perusahaan, sehingga jika struktur aset meningkat maka nilai perusahaan akan meningkat juga. Perusahaan dengan keuangan yang stabil memiliki nilai investasi yang tinggi berkenaan dengan aset tetap. Ketika aset tersebut dimanfaatkan secara optimal oleh staff yang kompeten, maka akan meningkatkan return perusahaan sehingga dapat memengaruhi penilaian perusahaan bagi investor atau informan lainnya. Hasil tersebut menunjukkan bahwa struktur aset memberikan sinyal yang positif bagi investor, sehingga sesuai dengan signalling theory struktur aset yang dimiliki perusahaan memberikan sinyal yang baik bagi investor. Struktur aset dan nilai perusahaan dapat dilihat pada grafik dibawah ini.

Grafik 3. Struktur Aset dan Price to Book Value

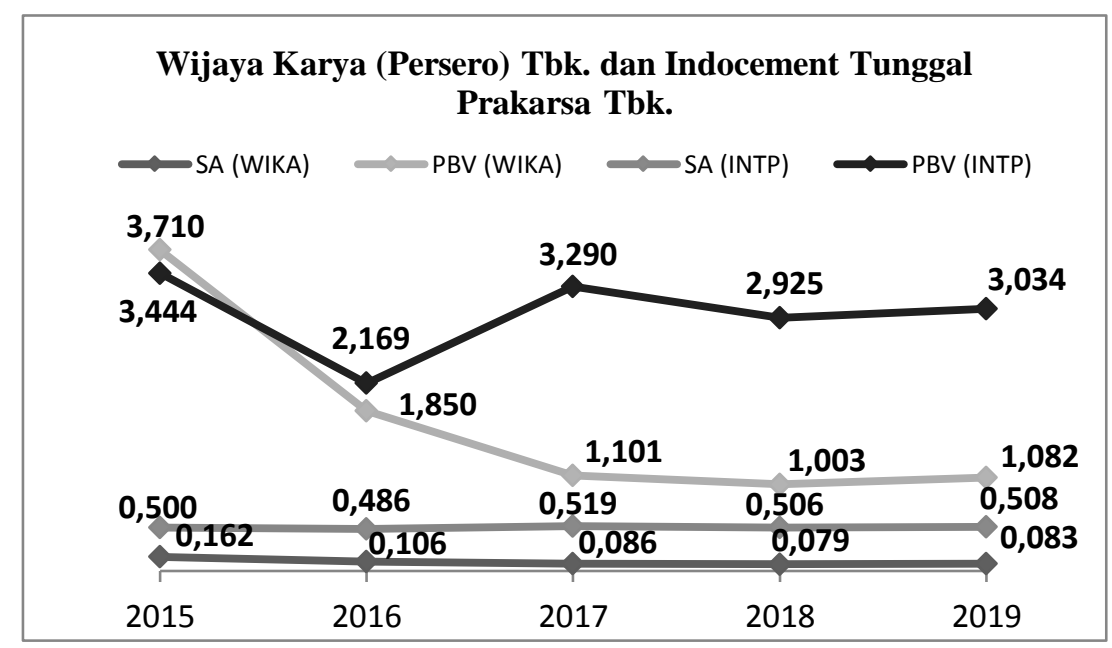

Berdasarkan Grafik 3 dapat diketahui bahwa struktur aset perusahaan Wijaya Karya (Persero) Tbk. mengalami penurunan tiga periode berturutturut diikuti dengan rendahnya Price to Book Value. Namun, pada tahun 
2019 struktur aset perusahaan tersebut mengalami peningkatan sebesar 0,083 diikuti tingginya Price to Book Value. Disisi lain, perusahaan Indocement Tunggal Prakarsa Tbk. juga mengalami penurunan di tahun 2016 yang diikuti oleh rendahnya Price to Book Value, sedangkan di tahun 2017 mengalami kenaikan diikuti tingginya Price to Book Value sebesar 3,290. Hal serupa dialami tahun berikutnya yang dapat dilihat pada Grafik 3 Penelitian ini membuktikan bahwa bahwa setiap perubahan yang terjadi pada struktur aset dapat memengaruhi nilai perusahaan.

Berdasarkan Tabel 5, dapat disimpulkan bahwa hipotesis yang menyatakan CEO Duality memiliki pengaruh positif terhadap nilai perusahaan diterima. Hasil pengujian ini mendukung penelitan Nayli \& Mardani (2018) yang membuktikan bahwa CEO duality mengindikasikan corporate governance memiliki pengaruh positif dan signifikan terhadap nilai perusahaan. Hal tersebut sesuai dengan teori agensi yang menjelaskan bahwa CEO duality dapat meminimalkan efektifitas pemantauan dewan komisaris dalam menjalankan tugasnya (Khakwani, Shahid, \& Hamza, 2016). Jabatan CEO yang merangkap sebagai ketua dewan komisaris tidak mengurangi integritas manajemen dalam meningkatkan nilai perusahaan. Secara substansial pengaruh CEO Duality terhadap nilai perusahaan diproksikan oleh Price to Book Value dapat dilihat dibawah ini.

Grafik 4. Price to Book Value

Kalbe Farma Tbk. dan Unilever Indonesia Tbk

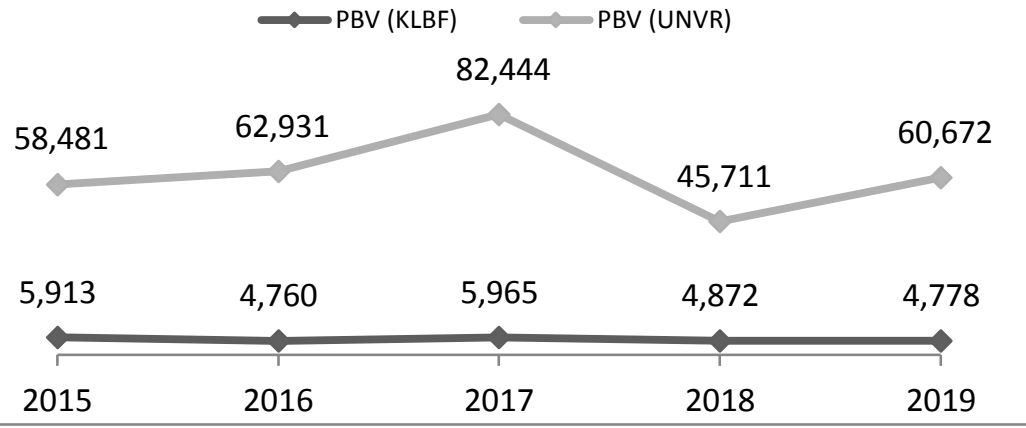

Grafik 4 menunjukkan bahwa Price to Book Value perusahaan Kalbe Farma Tbk. pada tahun 2017 mengalami peningkatan dimana pada tahun tersebut perusahaan melakukan perubahan struktur organisasi ditandai dengan adanya perangkapan jabatan dalam fungsi yang berbeda. CEO Duality dapat mengurangi potensi konflik antara CEO dan ketua dewan komisaris perihal arah organisasi. Disisi lain, terjadi kenaikan Price to Book Value pada perusahaan Unilever Indonesia Tbk. tahun 2016, 2017 dan 2019. Penelitian ini membuktikan bahwa rangkap jabatan dalam suatu perusahaan dapat meningkatkan nilai pasar saham. Selain itu, CEO Duality sebagai indikator dari corporate governance memberikan kekuatan bagi manajemen puncak, sehingga tidak membatasi kebebasan CEO dalam merencanakan dan melaksanakan strategi perusahaan. 
Terakhir, pengaruh proporsi komisaris independen terhadap nilai perusahaan menunjukkan pengaruh positif. Hasil pengujian ini sejalan dengan penelitian Rulimo et al., (2019) dan K. Dewi et al., (2019) yang membuktikan bahwa proporsi komisaris independen memiliki pengaruh positif terhadap nilai perusahaan. Proporsi komisaris independen yang besar dapat menciptakan corporate governance yang baik. Hal tersebut diakibatkan oleh mekanisme pemantauan yang kuat dari komisaris independen terhadap manajemen. Semakin besar proporsi komisaris independen menandakan kemampuan dewan komisaris untuk mengambil keputusan semakin objektif. Pengambilan keputusan yang objektif ini dapat memengaruhi harga saham perusahaan sehingga berdampak pada meningkatnya nilai perusahaan (Onasis \& Robin, 2016). Berikut ini adalah grafik yang menggambarkan proporsi komisaris independen perusahaan Unilever Indonesia Tbk. dan Astra International Tbk.

Grafik 5. Proporsi Komisaris Independen

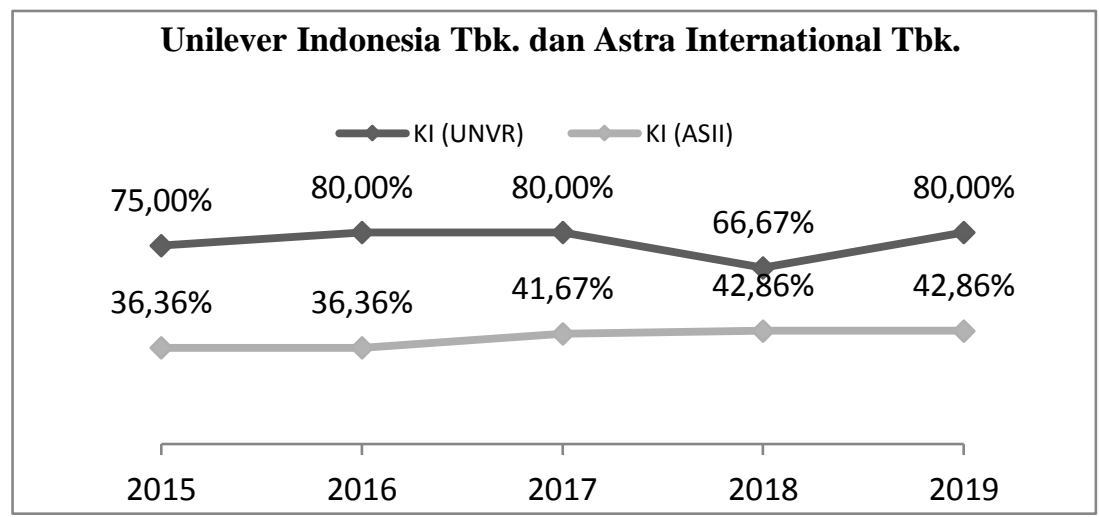

Berdasarkan Grafik 5 diatas dapat diketahui bahwa pada tahun 2016 proporsi komisaris independen perusahaan Unilever Indonesia Tbk. mengalami peningkatan seiring dengan perubahan Price to Book Value tahun tersebut yang dapat dilihat pada Grafik 4, sedangkan pada tahun 2017 proporsi komisaris independen bersifat konstan diikuti dengan peningkatan nilai pasar saham. Pada tahun 2018 proporsi tersebut mengalami penurunan disertai dengan rendahnya nilai pasar saham dan meningkat kembali di tahun 2019 meskipun proporsi yang ditunjukkan tidak ada perubahan. Disisi lain, proporsi komisaris independen perusahaan Astra International Tbk. hanya mengalami peningkatan di tahun 2017 saja. Namun Grafik 2 memperlihatkan bahwa Price to Book Value perusahaan tersebut kian meningkat setiap tahun.

Hasil penelitian ini menawarkan interpretasi secara teoritis dan empiris tentang faktor memengaruhi nilai perusahaan khususnya pada perusahaan manufaktur yang terdaftar di Jakarta Islamic Index (JII) sebagai sarana untuk mengonfirmasi hasil temuan penelitian sebelumnya. Hasil penelitian ini melengkapi hasil penelitian sebelumnya yang meneliti tentang faktor yang memengaruhi nilai perusahaan. Financial leverage yang memiliki pengaruh positif ini bertolak belakang dengan hasil penelitian Ibrahim \& Isiaka (2020), Al-Slehat (2020), Fajaria \& Isnalita (2018) yang menyatakan 
bahwa financial leverage berpengaruh negatif terhadap nilai perusahaan. Size (Ukuran Perusahaan) menguatkan hasil temuan sebelumnya yang dilakukan oleh Al-Slehat (2020), Aggarwal \& Padhan (2017) dan Rudangga \& Sudiarta (2016) yang membuktikan bahwa terdapat pengaruh positif antara size dan nilai perusahaan.

Selanjutnya penelitian ini mendukung penelitian sebelumnya oleh AlSlehat (2020) dan Setiadharma \& Machali (2017) yang membuktikan bahwa struktur aset memiliki pengaruh signifikan dan memiliki arah positif terhadap nilai perusahaan. Dan struktur Good Corporate Governance yang diukur dengan $C E O$ Duality dan proporsi komisaris independen yang menguatkan penelitian sebelumnya oleh Nayli \& Mardani (2018) yang membuktikan bahwa $C E O$ duality memiliki pengaruh positif dan signifikan terhadap nilai perusahaan dan Rulimo et al., (2019) dan Dewi et al., (2019) yang membuktikan bahwa proporsi komisaris independen memiliki pengaruh positif terhadap nilai perusahaan. Hasil tersebut membuktikan sesuai teori agensi dimana pemisahan kewenangan pada manajemen puncak menurunkan dapat menurunkan efektivitas pengambilan keputusan karena adanya konflik kepentingan. Sehingga dengan penerapan CEO Duality dan peningkatan proporsi komisaris independen meningkatkan kepercayaan stakeholder dalam pasar modal.

\section{SIMPULAN}

Penelitian ini bertujuan untuk menganalisis financial leverage, size, struktur aset dan corporate governance terhadap nilai perusahaan manufaktur yang terdaftar di Jakarta Islamic Index (JII) periode 2015-2019. Penelitian ini mengindikasikan financial leverage yang tinggi akan memberikan prospek perusahaan lebih baik yang dapat memicu investor untuk ikut meningkatkan permintaan saham. Permintaan saham yang meningkat akan disertai dengan meningkatnya nilai perusahaan, hal ini didukung oleh penelitian Lisa \& Sutama (2018). Selain itu, dapat diketahui juga bahwa perusahaan berskala besar dapat menjadi sinyal yang baik bagi investor sehingga investor akan merespon secara positif sehingga mengakibatkan kenaikan harga saham. Hal ini mendukung signalling theory yang menjelaskan bahwa ukuran perusahaan yang besar dapat memberikan sinyal bagi investor yang menaruh perhatian kepada perusahaan.

Selanjutnya, struktur aset yang tinggi memiliki dana internal yang besar, sehingga perusahaan tersebut akan cenderung menggunakan dana internalnya terlebih dahulu sebelum menggunakan pembiayaan eksternal dalam mengoperasikan perusahaan Selain itu, semakin besar struktur aset diharapkan memberikan peningkatan pada operasional yang dihasilkan oleh perusahaan. Peningkatan struktur aset yang diikuti peningkatan hasil operasi akan semakin menambah kepercayaan pihak luar terhadap perusahaan. Dengan demikian, Struktur aset memainkan peranan penting dalam menentukan pembiayaan perusahaan sehingga dapat memaksimalkan nilai perusahaan. 
Penelitian ini membuktikan bahwa semakin banyak anggota komisaris independen dapat memicu nilai perusahaan semakin tinggi dan sebaliknya. Karena adanya komisaris independen akan mengurangi kecurangan dalam pelaporan keuangan dan diharapkan dapat meningkatkan efektivitas pengawasan suatu perusahaan. Selain itu, proporsi komisaris independen yang bersifat konstan mampu memberikan pandangan terbaiknya selama tidak ada penurunan pada nilai pasar saham. Sehingga, pengawasan yang efektif dari komisaris independen dapat mendatangkan investor untuk menginvestasikan dananya pada perusahaan dengan nilai perusahaan yang tinggi.

Pengukuran nilai perusahaan yang hanya menggunakan satu indikator yaitu rasio pasar (Price to Book Value) dan dua indikator dalam mengukur variabel corporate governance menjadi kelemahan dalam penelitian ini. Penelitian berikutnya diharapkan memperluas sampel penelitian, tidak hanya melakukan penelitian pada sektor manufaktur saja melainkan pada sektor perusahaan yang berbeda. Penelitian berikutnya juga perlu menggunakan indikator lain agar memperoleh gambaran variabel lain yang dapat menjelaskan pengaruh nilai perusahaan.

\section{DAFTAR PUSTAKA}

Aggarwal, D., \& Padhan, P. C. (2017). Impact of Capital Structure on Firm Value: Evidence from Indian Hospitality Industry. Theoretical Economics Letters, 7, 982-1000. https://doi.org/10.4236/tel.2017.74067

Al-Slehat, Z. A. F. (2020). Impact of Financial Leverage, Size and Assets Structure on Firm Value: Evidence from Industrial Sector, Jordan. International Business Research, 13(1), 109-120. https://doi.org/10.5539/ibr.v13n1p109

Al Ani, M. K. (2014). Effects of Assets Structure on the Financial Performance: Evidence From Sultanate of Oman. Journal of US-China Public Administration, 11(2), 170-179.

Atmaja, L. S. (2008). Manajemen Keuangan. Yogyakarta: Andi.

Babatunde, M. A., \& Olaniran, O. (2009). The effects of internal and external mechanism on governance and performance of corporate firms in Nigeria. Corporate Ownership \& Control, 7(2), 330-344.

Barakat, A. (2014). The Impact of Financial Structure, Financial Leverage and Profitability on Industrial Companies Shares Value (Applied Study on a Sample of Saudi Industrial Companies). Research Journal of Finance and Accounting, 5(1), 55-66.

Brigham Eugene, F., \& Joe, F. (2006). Houston.(2006). Dasar-Dasar Manajemen Keuangan. Alih Bahasa Ali Akbar Yulianto. Buku Satu. Edisi Sepuluh. Jakarta: Selemba Empat. 
Craig, S. (2005). IT Governance Framework-Best Practices. Forrester Research, 1-17.

Dewi, K., Rasmini, N. K., \& Ratnadi, N. M. D. (2019). The Effect of Independent Board of Commissioners, Institutional Ownership, and Managerial Ownership in Firm Values with Environmental Disclosure as Moderating Variable. International Journal Sciences: Basic and Apllied Research, 48(2), 53-67.

Fajaria, A. Z., \& Isnalita. (2018). The Effect of Profitability, Liquidity, Leverage and Firm Growth of Firm Value with its Dividend Policy as a Moderating Variable. International Journal of Managerial Studies and Research, 6(10), 55-69. https://doi.org/10.20431/2349-0349.0610005

Fama, E. (1980). Agency problems and theory of the firm. Journal of Political Economy, 88, 288-307.

Fama, E. F., \& Jensen, M. C. (1983). Agency problems and residual claims. The Journal of Law and Economics, 26(2), 327-349.

Fatoni, H. A., \& Sulhan, M. (2020). Pengaruh Good Corporate Governance Terhadap Nilai Perusahaan Dengan Profitabilitas Sebagai Variabel Mediasi. Ekspansi: Jurnal Ekonomi, Keuangan, Perbankan Dan Akuntansi, 12(1), 77-94. https://doi.org/10.35313/ekspansi.v12i1.1888

Ghozali, I. (2013). Aplikasi Analisis Multivariate dengan Program IBM 23. Semarang: Badan Penerbit Universitas Diponegoro.

Ibrahim, U. A., \& Isiaka, A. (2020). Effect of Financial Leverage on Firm Value: Evidence From Selected Firms Quoted on the Nigerian Stock Exchange. European Journal of Business and Management, 12(3), 124-135. https://doi.org/10.7176/ejbm/12-3-16

Indriyani, E. (2017). Pengaruh Ukuran Perusahaan dan Profitabilitas Terhadap Nilai Perusahaan. Akuntabilitas: Jurnal Ilmu Akuntansi, 10(2), 333-348. https://doi.org/10.15408/akt.v10i2.4649

Jensen, M. C., \& Meckling, W. H. (1976). Theory of the Firm: Managerial Behavior, Agency Costs and Ownership Structure Theory of the Firm : Managerial Behavior, Agency Costs and Ownership Structure.

Khakwani, M. S., Shahid, M. S., \& Hamza, A. (2016). Effect of Corporate Governance and Financial Leverage on Market value Added in Pakistan. Journal of Accounting and Finance in Emerging Economies, 2(1), 17-26. https://doi.org/10.26710/jafee.v2i1.49

Lisa, E., \& Sutama, dedi R. (2018). Pengaruh Leverage dan Profitabilitas terhadap Nilai Perusahaan (Studi pada Perusahaan Sektor Manufaktur Food and Beverage yang terdaftar di Bursa Efek Indonesia). Jurnal Sains Manajemen Dan Akuntansi, X(1), 21-39.

Mardiyanto, H. (2009). Intisari Manajemen Keuangan. PT. Gramedia Widiasarana Indonesia. 
Mawikere, C. Y., \& Rate, P. Van. (2015). Pengaruh Stabilitas Penjualan Struktur Aktiva Terhadap Struktur Modal Perusahaan Automotive and Allied Product yang Terdaftar di BEI Periode 2010-2013. Jurnal EMBA, 3(3), 149-159.

Modigliani, F., \& Miller, M. H. (1958). The cost of capital, corporation finance and the theory of investment. The American Economic Review, 48(3), 261-297.

Nayli, I., \& Mardani, R. M. (2018). Analisis Pengaruh Good Corporate Governance Terhadap Nilai Perusahaan. E-Jurnal Riset Manajemen.

Nurhaiyani. (2018). Pengaruh Corporate Governance, Leverage Dan Faktor Lainnya Terhadap Nilai Perusahaan Non-Keuangan. Jurnal Bisnis Dan Akuntansi, 20(2), 107-116. https://doi.org/10.34208/jba.v20i2.415

Nyamasege, D., Okibo, W. B., Nyang'au, A. S., \& Sang'ania, P. O. (2014). Effect of Asset Structure on Value of A Firm : A Case of Companies Listed in Nairobi Securities Exchange. Reseacrh Journal of Finance and Accounting, 5(9), 97-103.

Obradovich, J., \& Gill, A. (2012). The Impact of Corporate Governance and Financial Leverage on the Value of American Firms. International Research Journal of Finance and Economics, (91), 1-14.

Okiro, K., Aduda, P. J., \& Omoro, N. (2015). The Effect of Corporate Governance and Capital Structure on Performance of Firms Listed at Rhe East African Community Securities Exchange. European Scientific Journal, 11(7), 504-533.

Oktaviani, M., Rosmaniar, A., \& Hadi, S. (2019). Pengaruh Ukuran Perusahaan (SIZE) dan Struktur Modal Terhadap Nilai Perusahaan. Jurnal Balance, XVI(1), 102-111.

Onasis, K., \& Robin. (2016). Pengaruh Tata Kelola Perusahaan terhadap Nilai Perusahaan pada Perusahaan Sektor Keuangan yang Terdaftar di BEI. Bina Ekonomi, 20(1), 1-22. https://doi.org/10.26593/be.v20i1.1893.1-22

Onyenwe, N. I., \& Glory, I. (2017). Effect of Financial Leverage on Firm's Performance: A Study of Nigerian Banks (2006-2015). International Journal of Recent Scientific Research, 8(7), 18554-18564. https://doi.org/10.24327/IJRSR

Permatasari, N. putri, Isharijadi, I., \& Wihartanti, L. V. (2020). Pengaruh EPS, PER dan PBV Terhadap Harga Saham (Studi Pada Perusahaan Sektor Manufaktur yang terdaftar di JII). Jurnal Akuntansi Netral, Akuntabel, Objektif, 2(2), 284-292.

Pribadi, M. T. (2018). Pengaruh Struktur Aset, Ukuran Perusahaan, Likuiditas Dan Profitabilitas Terhadap Nilai Perusahaan Dagang Besar Yang Terdaftar di Perusahaan Bursa Efek Indonesia. Progress 
Conference, 1(1), 372-385.

Purwanti, T. (2020). The Effect of Profitability, Capital Structure, Company Size, and Dividend Policy on Company Value on the Indonesia Stock Exchange. International Journal of Seocology, 1(2), 60-66. https://doi.org/10.29040/seocology.v1i02.9

Purwohandoko. (2017). The Influence of Firm's Size, Growth, and Profitability on Firm Value with Capital Structure as the Mediator: A Study on the Agricultural Firms Listed in the Indonesian Stock Exchange. International Journal of Economics and Finance, 9(8), 103110. https://doi.org/10.5539/ijef.v9n8p103

Putra, R. N. A. (2016). The Effect of Board Governance on Firm Value. Efektif Jurnal Ekonomi Dan Bisnis, 7(2), 87-108.

Rosada, F. L. A., \& Idayati, F. (2017). Pengaruh Profitabilitas Terhadap Nilai Perusahaan Otomotif Di Bursa Efek Indonesia. Jurnal Ilmu Dan Riset Akuntansi, 6(1), 256-274.

Rudangga, I. G. N. G., \& Sudiarta, G. M. (2016). Pengaruh Ukuran Perusahaan, Leverage, Dan Profitabilitas Terhadap Modal Intelektual Perusahaan. E-Jurnal Manajemen Universitas Udayana, 5(7), 43944422.

Rulimo, P. L., Alam, S., \& Pakki, E. (2019). Tekstildan Garment Yang Terdaftar, 05(02), 153-164.

Safitri, N., \& Wahyuati, A. (2015). Pengaruh Struktur Modal Dan Keputusan Investasi Terhadap Profitabilitas Dan Nilai Perusahaan. Jurnal Ilmu Dan Riset Manajemen, 4(2), 1-17. https://doi.org/10.25105/jat.v2i1.4829

Setiadharma, S., \& Machali, M. (2017). The Effect of Asset Structure and Firm Size on Firm Value with Capital Structure as Intervening Variable. Journal of Business \& Financial Affairs, 6(4), 1-5. https://doi.org/10.4172/2167-0234.1000298

Smith, C. W., \& Warner, J. B. (1979). Bankruptcy, secured debt, and optimal capital structure: Comment. The Journal of Finance, 34(1), 247-251.

Sobirin, A. (2007). Budaya Organisasi (Pengertian, Makna dan Aplikasinya dalam Kehidupan Organisasi). Yogyakarta: UPP, STIM YKPN.

Sofia, N. N., \& Akhmadi. (2018). Pengaruh Profitabilitas dan Ukuran Perusahaan Terhadap Nilai Perusahaan dengan Kebijakan Hutang Sebagai Variabel Intervening. Tirtayasa Ekonomika, 13(1).

Suharyadi, \& Purwanto, S. K. (2017). Statistika untuk Ekonomi dan Keuangan Modern (Cetakan Ke). Jakarta: Salemba Empat.

Ukhriyawati, C. F., Ratnawati, T., \& Riyadi, S. (2017). The Influence of Asset Structure, Capital Structure , Risk Management and Good 
Corporate Governance on Financial Performance and Value of The Firm through Earnings and Free Cash Flow As An Intervening Variable in Banking Companies Listed in Indonesia Sto. International Journal of Business and Management, 12(8), 249-260. https://doi.org/10.5539/ijbm.v12n8p249

Zuhroh, I. (2019). The Effects of Liquidity, Firm Size, and Profitability on the Firm Value with Mediating Leverage. KnE Social Sciences, 3(13), 203-230. https://doi.org/10.18502/kss.v3i13.4206 
